\title{
WALT WHITMAN AND ASIAN AMERICAN WRITERS
}

\author{
XILAO Li
}

WhitMAN OBSERVES IN AN UNPUBLISHED NOTE that Columbus's original goal was to find a passage to Asia, but he discovered instead "a New World America." So his futile purposes "result in great results." In "Passage to India" Whitman celebrates the construction of the first transcontinental railroad in America in 1869, the opening of the Suez Canal, and the laying of underwater telegraph cable, as the long-deferred verification of Columbus's dream of the linking of the East and West:

Ah Genoese thy dream! thy dream!

Centuries after thou art laid in thy grave,

The shore thou foundest verifies thy dream. ${ }^{2}$

As Whitman saw it, the invention of the new networks revealed a divine design to interlock the "Old Asia" and the "New World." Unlike his materialistic contemporaries, he believed that the enterprise had a spiritual significance: the oceans would be crossed, the lands spanned, and the different races would "marry and be given in marriage" $(C P C P$, 532).

History tells us that it is the East that crossed the Pacific to meet the West. In the late 1840s, following with the tide of the gold rush in California, large numbers of immigrants came wave upon wave to the American West from a different shore. The Chinese pioneers, mostly farmers in the southern coastal area, driven by heavy tax, famine, hunger, strifes, wars, and other economical and social pressures in a rapidly declining feudalistic empire, grabbed the opportunity to seek sanctuary and to pursue a better life in a land they called the Gold Mountain. They came as laborers, working in the mines, laying tracks for the transcontinental railroads, reclaiming swamp lands, doing farm work and providing laundry and restaurant services. The Chinese immigrants constituted an indispensable force in the developing of the American West.

On the eve of this mass migration, on July 14, 1847, a "Chinese junk" was on exhibition in New York. In the Brooklyn Daily Eagle, Whitman first dismissed it as a hoax, "a humbug from stem to stern." 
Then on August 6, apparently accepting the Chinese crew as authentic, Whitman reported the visit of two of them to Greenport, Long Island, by train, and he wrote of their impressions of American railways: "Hesing and Sum Teen, . . . for the first time since their arrival, exhibited astonishment and delight. ... . The speed of the train absolutely brought their queues to a complete perpendicular with fright."3 Some twenty years later, tens of thousands of Hesing and Sum Teen's Chinese brethren were building the Central Pacific Railroads, changing the contours of America's landscape.

Doubtless, Whitman was deeply attracted to the cultures of the East. The great Indian poet Tagore observed in 1916, "Whitman's poems, though strongly savoring of America, are yet deeply imbued with Eastern ideas and feelings." 4 When a friend came back from China, Whitman talked to him and made detailed notes of what he heard. When Thoreau asked him if he had read any Orientals, Whitman's answer showed his eager interest-"No: tell me about them."5 He was present at a banquet in 1868 given by the U.S. President in the honor of the Chinese embassy staff in celebration of the opening of trade and diplomatic relations with China. In his poetry he made numerous allusions to things Asian, greeting Asia and its civilizations with great enthusiasm in "Salut au Monde!"

In June 1860 a Japanese delegation of diplomats was given a welcoming parade in Manhattan. This occasioned the poem "The Errand Bearers," later renamed "A Broadway Pageant," in which Whitman welcomes the arrival of the Japanese as the envoy of "the Orient," "the Asiatic continent." With them, the poet writes, comes "the Originatress" - "the nest of languages, the bequeather of poems, the race of eld." (CPCP, 384). Whitman seems to have shared Hegel's view that the history of the world travels from East to West, with Europe as "absolutely the end of History, Asia the beginning." The difference, though, is that Hegel's view is a Eurocentric, linear hierarchy, whereas Whitman's looks more like a circular, rounded globe. He extends the development of world civilization to the new continent and looks forward to the meeting of the West and the East as the consummation of the "rondure of the world" $(C P C P, 533)$. In one of his notes, Whitman believes that the meeting of East and West in the New World is not only "the completion of the Orbic Circle" but also shapes the destiny of the United States. He predicts that the joining of the Old Asia- "the traditional commencement \& origin of the Race in Asia"-and the New World-“"the rounding of the long journeys of Humanity and Civilization"-will "surely play so large a part in both the Real and Ideal future of The United States" (NUPM, 1:925).

As early as 1856, in his letter to Emerson, Whitman expresses his welcome to all those "immigrants from Europe, Asia, Africa" and 
consciously incorporates them into the scheme of the forging of a new American national character $(C P C P, 1336)$. However, despite the Chinese immigrants' historic exploits in the opening up of the West, they fell victims to racism and were treated as the hateful heathen "Other," suffering untold humiliation and atrocity. Representing the Municipality of San Francisco before the Congressional Committee of 1876, a racist named Frank Pixley argued with a robber's logic:

The Chinese are inferior to any race God ever made. . . . [The Divine Wisdom] inspired us with the determination, not only to have prepared our own inheritance, but to have stolen from the Red Man, America; and it is now settled that the Saxon, American or European groups of families, the White Race, is to have the inheritance of Europe and America and that the Yellow races are to be confined to what the Almighty originally gave them; and as they are not a favored people, they are not to be permitted to steal from us what we have robbed the American savage of. . . .7

Horrified by an imagined invasion of the "Yellow Peril," the U.S. Congress passed the first Chinese Exclusion Act in 1882 and thus legitimized discrimination against an ethnic group. In 1888, in the face of the Presidential election, the politicians in the Congress, both the Democrats and Republicans, wooed votes by emphasizing their antiChinese records. As a result, the Scott Act, yet another restrictive law against the Chinese immigrants, was passed. As the Chinese question came to a head as a national issue, some of Whitman's conversations recorded by Horace Traubel provide us with clues to his stand.

In May 1888, over a heated debate about restriction on foreign immigrants, Whitman sided with those who were accused of being forever "foreign" and "unassimilable," believing that "All that man needs to be good is the chance. History has so far been busyinstitutions, rulers, have been busy-denying him that chance." Whitman went so far as to threaten to renounce his American citizenship if his country insisted on its discriminative policies: "In that narrow sense I am no American - count me out." ${ }^{\text {"8 }}$ The choice seemed obvious to him between the people who were making America and the government which ran counter to the real meaning of America:

Restrict nothing - keep everything open: to Italy, to China, to anybody. I love America, I believe in America, because her belly can hold and digest all . . . hold and digest all. If I felt that America could not do this I would be indifferent as between our institutions and any others. (Traubel, 1:113)

On June 20 Whitman more specifically expressed his disgust with those anti-Chinese politicians whose crying wolf was a direct challenge to the idea of America as a home, a haven for all people. Prominent among those agitators was James G. Blaine, Senator of Maine. In 1879 Blaine voiced his unfounded conclusion: "The Asiatic cannot go on with 
our population and make a homogeneous element."9 $\mathrm{He}$ was one of the leading sinophobes whose efforts secured the passage of the Exclusion Acts by the Congress. Whitman dissociated himself from Blaine and his like:

I hate Blaine's protectionism and anti-Chinese principles. . . . The whole gang is getting beyond me: I find it harder and harder every year to reconcile myself to the exhibit they make: they narrow, narrow, narrow every year: after awhile I'll be altogether without a political home unless I build one for myself. (Traubel, 1:359)

Whitman found himself alienated in an America which denied the Asian Americans entry to the new home they sought in the New World. To him, kicking the Chinese out and slamming the door against immigrants from the East was nothing short of an American tragedy, a failure of democracy itself. On July 24 Whitman reiterated his longstanding espousal of the principle of a multi-ethnic, democratic America:

America must welcome all-Chinese, Irish, German, pauper or not, criminal or not-all, all, without exceptions: become an asylum for all who choose to come. . . . America is not for special types, for the castes, but for the great mass of people-the vast, surging, hopeful, army of workers. Dare we deny them a home-close the doors in their face-take possession of all and fence it in and then sit down satisfied with our system-convinced that we have solved our problem? I for my part refuse to connect America with such a failure-such a tragedy, for tragedy it would be. (Traubel, 2:34)

In the most trying moment in the history of the Chinese Americans, Whitman's remarks, though desultorily recorded in Traubel's memoir, prove that he was indeed one of their friends in need. Whitman was not merely showing pity for the Chinese Americans. He made it a matter of principle that exclusion and discrimination of any group of American people because of its ethnicity would only spell the death of America. In an 1883 letter, "The Spanish Element in Our Nationality," he declares that America is not a "second England . . . impress'd by New England writers and schoolmasters." He stresses that America's "antecedents," which are of "many sources," must be reinstated to "counterbalance" the British and German "excess," and to contribute to the "composite American identity of the future" (CPCP, 1147). No wonder that Ronald Takaki, author of a new history of Asian Americans, places Whitman right in the center of "a counter tradition and vision" in American history, "springing from the reality of racial and cultural diversity."10

To "take ship" to seek a spiritual passage to Asia-the cradle of humanity, religion and culture-was Whitman's dream. While his 
imagination was taking its flight, large numbers of Chinese started coming to the Gold Mountain, crossing the Pacific. They were to be followed by Japanese, Korean, Filipino and other Asian immigrant groups. Perhaps many came first as sojourners. But when they settled down, they built a home away from home, and transformed themselves into a new people-Asian Americans. ${ }^{11}$ Their sons and daughters were fated to grapple with the meaning of being a yellow-skinned American. In their quest for identity, Asian American writers have discovered a white American named Whitman who extends them his welcome and assures them that they are not at all too late for the enterprise of the making of America.

Sadakichi Hartmann, born in Japan in 1867 to a German father and a Japanese mother, identified himself more with his Japanese American experience which began when he came to America as a teenage student. Residing in California during the Pacific War, he was suspected of being a Japanese agent and was subjected to harassment and insults. His stance against racism and his ethnic consciousness, according to David Wand, "makes him contemporary in spirit and acceptable to the majority of postwar Asian-American poets, who are concerned with the rediscovery of their ethnic heritage." 12

While a young student at Philadelphia, Hartmann sought out Whitman in Camden and began to visit the old man in 1884 . He recalled that Whitman recognized his Japanese nationality "at the first glance."13 Meeting someone of Japanese ancestry gave Whitman an occasion to comment on the ethnicity of America. As an immigrant student, Hartmann considered himself "a late addition to the conglomeration called Americans" (Hartmann, 5). Whitman talked to him as if the two shared a common experience. "I never forget that my ancestors were Dutch," said Whitman (Hartmann, 7).

Hartmann became a self-claimed disciple. He wrote a number of prose poems in imitation of Whitman. At one point he even thought of becoming Whitman's voluntary nurse. But their relationship was finally not a very happy one, although various aspects of it reveal Whitman's characteristic ambivalences and contradictions. Learning that the foreign student was contemplating a study of Shakespeare's fools, Whitman shook his head: "I fear that won't go. There are so many traits, characteristics, Americanisms, inborn with us, which you would never get at. . . . After all one can't grow roses on a peach tree" (Hartmann, 8). Whitman seemed to believe that a total acculturation of immigrants to "Americanism" was impossible, forgetting that, with the possible exception of Indians, all Americans were and are of transplanted breeds.

Later, Hartmann's publication of Whitman's conversational remarks about contemporary writers irked, instead of pleased, the master. Whitman angrily denied Hartmann's report and suspected the motives 
behind Hartmann's founding of a quickly aborted Whitman Society. Whitman repudiated Hartmann on several occasions, calling him "a dangerous fellow" and accusing him of lack of integrity (Traubel, 5: 35). In his anger, Whitman allowed biased views about intermarriage and the Asian race to surface; he said of Hartmann in 1889: "It is in him something basic-something that relates to origins . . . Hartmann-oh! have you never seen him? He is a biggish young fellow-has a Tartaric face. He is the offspring of a match between a German - the father-and a Japanese woman: has the Tartaric makeup." Whitman then added, "and the Asiatic craftiness, too-all of it!" (Traubel, 5:38). Hartmann's character is not our concern here, but when Whitman attributed a certain base character to the Asian race, it only shows that no one can be entirely free of the racial prejudices of his time. This Whitman seems to share little with the poet who almost apotheosized the Oriental cultures while cheering the arrival of the Japanese envoy in the midst of " $\mathrm{A}$ Broadway Pageant" two decades earlier.

Hartmann admitted that differences developed between him and Whitman as he matured as a writer in his own right. Accompanied by his wife, Hartmann paid his last visit to Whitman in March 1891. Perhaps Whitman was magnanimous in agreeing to receive his disavowed disciple, or perhaps he realized some mistake or misunderstanding on his part in his treatment of Hartmann. But what is admirable is Whitman's "toleration and hospitality": "I take in all the fellows-omit no one" (Traubel, 7:92). At the report of Whitman's death a year later, Hartmann went to the New York Central Park and held "a silent communion with the soul atoms of the good gray poet" (Hartmann, 49). Reviewing his acquaintance with Whitman, Hartmann had nothing to regret: it was "the most satisfactory," and their relation was "after all very much like that of a disciple to his master" (Hartmann 50).

A few years after this communion, another young Japanese came to America and soon was captivated by Whitman's influence. In California, Yone Noguchi became associated with Western writers like Joaquin Miller, and it was probably through Miller that Noguchi was attracted to Whitman's poetry. ${ }^{14}$

As Yoshinobu Hakutani has pointed out, Noguchi's first book, Seen and Unseen, shows the unmistakable influence of Whitman and Joaquin Miller. Apart from drawing on the Japanese tradition, Noguchi's poems are reminiscent of Whitman in their closeness to nature and in the sweeping lines. Noguchi's komos in "My Universe" has similar manifestations of Whitman's "Self." Like Whitman, Noguchi believed in monism, and his ultimate goal in writing poetry was to achieve the ecstasy of the self in nature. After Noguchi returned to Japan, Whitman's influence continued. His son, Isamu Noguchi, a noted sculptor, confirmed this influence in an interview. The son said 
that his father, like Whitman, was energized by the spirit of the American frontier. "In the case of my father, I think," Isamu said, "he became a pioneer American in a sense with the eyes of an Oriental . . . like all these people whose eyes were open to the ideal of the American frontier-from Whitman and Joaquin Miller down to Pound, Dreiser, and so on."15 Noguchi returned to Japan as a trans-cultural poet and critic.

Lin Yutang, a prolific Chinese American writer, played a similar role as a cultural envoy. Versed in Chinese studies, he enjoyed enormous popularity as a learned, humane, witty, and sometimes commonsensical interpreter of Chinese culture to American audiences; his favorite couplet was "With two feet I span the cultures of both the East and West; / With a sole heart I critique writings all over the world." Lin believed that the highest goal of culture was the cultivation of an ideal human life, and the criterion of any culture was what type of men and women that culture produced. Lin described his philosophy of living as "the Chinese version of the American doctrine of individualism." "It is not surprising that Lin spent over three decades living in America and managed to keep himself away from Chinese immigrants' life and to stand aloof from the social and political strife in China. His largely egoistic philosophy and elite life style in America generated a lot of criticism from Chinese in both America and China. ${ }^{17}$ In his novel Chinatown Family (1948) Lin attempted to depict the life of Chinese immigrants in New York's Chinatown, but - as a result of the author's lack of intimate knowledge of the seamy side of Chinese American experience-the portrayals of Chinese immigrants were often stereotypes.

Because Whitman espoused "the principle of individuality or "personalism' as the end of all civilization," Lin applauded him as "one of the wisest and most far-seeing of Americans" ( $\mathrm{Lin}, 89)$. It is in this sense that Lin responded to Whitman's call for a new type of man in the image of Whitman's Self. In The Importance of Living, Lin asks contentedly, "What can be the end of human life except the enjoyment of it?" He quotes Whitman's lines to support his almost blind belief in the supremacy of individualism. "As Whitman says," Lin writes, "I am sufficient as I am.' It is sufficient that I live-and am probably going to live for another few decades - and that human life exists" (Lin, 124). Lin also quotes from Specimen Days to reinforce his own emphasis on the sensual appreciation of living: "And see how Whitman's senses of smell and sight and sound contribute to his spirituality and what great importance he places upon them ..." (Lin, 129). Lin's discussion of Whitman is limited to the poet's extolling of personal fulfillment and sensual enjoyment of life. Clearly, it is Lin's own individualistic world outlook that prescribed his tendency to appropriate Whitman as the 
model of a laudable culture of personalism.

Younghill Kang is remembered today as the first accomplished Korean American writer. He came to America as an immigrant student in 1921. As a transitional figure "from authors who view themselves as guests or visitors to those who want to find a place for themselves in American society,"18 Kang underwent agonizing and restless experiences resulting from the conflict between the cultures of East and West. The tension is well expressed in the title of his autobiographical novelEast Goes West: The Making of An Oriental Yankee (1937).

At the age of eighteen, the protagonist Chungpa Han, like the author, comes to America to "hunt for the spiritual home."19 The first thing Han does upon his arrival in New York is to try to shed his past and cleanse himself thoroughly in a fancy hotel: "I was washing off the dirt of the Old World that was dead" (Kang, 12). However, the second night finds poor Han huddling up with the New York homeless in a slum basement. Filled with the American Dream to pursue and enjoy opportunity and success, truth and knowledge of the West, Han plummets overnight into the harsh realities of American society. $\mathrm{He}$ is initiated into the first lesson of his American education. The aspiring Oriental scholar is forced to struggle for his existence, working as a waiter, a servant, a salesman, a farmhand, a housekeeper, and a clerk.

Worse yet, Han realizes that on the way to the making of an Oriental Yankee there stand racial obstacles. In college he is called "the yellow dog" (Kang, 103). While staying with the New England Livelys, he hears his hostess harshly criticize his friend Jum for going around with a white girl. And Mr. Lively warns Han not to get "wrong ideas," for he wouldn't want to see his daughter marrying an Oriental. The boundary is sacred: "It is not as the Lord intended" (Kang, 161). Another friend of his, Kim, also falls victim to this invisible racist barrier. Kim's girlfriend's family condemns him for passing the barriers that "were never meant to be broken" (Kang, 288). The lovers are set apart, and their love ends tragically.

Han quickly learns that in this white man's world, Asians are not the only outcasts. Blacks, Jews, Italians, and other ethnic groups are all slighted and rejected. One of his friends is a hard-working black student named Wagstaff, "always poor and struggling" (Kang, 296). Working "like hell" to get a higher education, Wagstaff tells his Asian friend: "What room is there in America for an educated Negro?" He adds with bitterness, "the more American culture I absorb, the more Whitman, Emerson, Lincoln I read, I give you my word, the more hatred and revengeful spirit I have" (Kang, 296). Han knows very well what Whitman wrote about. Earlier in the novel, he browsed books from shelf to shelf in libraries, "like a hungry cow eating grass in a valley" (Kang, 262). Among other writers, Han read Hawthorne, Cooper, Poe, 
Melville, and last but not least, Whitman. Another time, he was cataloguing Mr. Schmitt's private library. There were Kant, Emerson, Carlyle, Poe, Goethe, Mullner, Schiller, Schopenhauer, Lessing, Klopstock, Schleiermacher, and to Han's pleasant surprise, "even Whitman and Melville." Han had the library all to himself "to work and dream in" (Kang, 283). America had strayed too far from the ideal of the "greatest democratic country of the world" (Kang, 297) that Han came to find in Whitman.

Although he shares many of Wagstaff's ideas and experiences, Han cannot bring himself to agree with his black friend's conclusion. Instead of getting more revengeful and hateful, Han becomes an advocate for racial harmony in America. His awareness of the common destiny of the oppressed minorities in America is ironically confirmed by the scheme of a fanatic Elder Bonheure to use him and a Jew named Ginsburg as two heathen examples in a religious ritual: "Jews and Chinamen to be sanctified!" (Kang, 362). Whitman's hope of America as a sanctuary for all people as brothers and sisters is turned upside down. In Bonheure's "Temple of Saints," Han witnesses the exploitation and oppression of Negroes, Jews, the poor, and women - all under the name of "Sisterhood" and "Brotherhood." When he is maneuvered to preach, Han uses this absurd occasion to teach Whitman's "Song of Myself" and his new religion of brotherhood and sisterhood. Like Whitman, Han tries to incite those hoodwinked Americans into new consciousness:

I preached on racial prejudice, using Walt Whitman as text. And I told them to wake up, wake up and join the world of higher things, "Make something of yourselves. Be educated." My voice was fervent too. I was deeply moved. (Kang, 367)

Han urged the wretched Americans in the Temple of Saints to stand up and reassert their human dignity.

Afterwards, exploring and travelling on the open road, Han comes to know America firsthand. He talks to all kinds of people. Some tell him that America is a rotten country. Others encourage him: "Believe in America with all your heart. Even if it's sometimes hard, believe in her. . . . I tell you, sir, you belong here. You should be one of us" (Kang, 383). Despite all his hardships, Han holds on to his American Dream, symbolized by his pursuit of a white American girl, Trip, who is "mystically interwoven into my whole dream of America" (Kang, 384). Younghill Kang concludes his novel with a dream in which Han and some African Americans are trapped in a big city's dark cellar, attacked by men with clubs, knives and torches, and burned alive. But Han, awakened "like the phoenix out of a burst of flames," has an upbeat interpretation of this nightmare: "death by fire augurs good fortune" (Kang, 401). It is Kang's hope that through fire and violence 
will come the regeneration of a Whitmanian, democratic, multi-ethnic America.

Perhaps among Asian American writers of the 1940s, the most eloquent spokesman for Asian immigrants was Carlos Bulosan, a Filipino American writer. His America Is in the Heart (1943) is now regarded as a classic of Asian American literature. Interestingly, Bulosan's desire to become a writer using English was aroused by the examples of Younghill Kang and Yone Noguchi. After reading Kang's autobiographical novels, Bulosan made up his mind to become an Oriental writer in America, even without education. In ransacking the library for biographies, he came upon Noguchi who started as a "Japanese houseboy in the home of Joaquin Miller" but turned into "the first poet of his race to write in the English language."20 Above all, it is to Whitman that Bulosan owed his "American Dream."

When he was barely twenty years old, full of hope for a better life in America, Bulosan, a poor Filipino farmer's son, sailed in 1930 to an America which was sinking into the deepest depression ever known. Like other Filipino immigrants, he lived with daily incidents of violence, exploitation, and discrimination on the West coast. Racism and economic pressures went hand in hand to create a widespread hostility against Filipino farmers. They were expelled from farming towns. Those who had dared cross the boundaries for interracial love were specially singled out as easy targets for white racists' hatred.

To express his own frustration and anger, and to give a voice to the voiceless thousands of Filipinos in America, Bulosan began to read voraciously. He "relished Whitman" and other writers, as a witness recalled. ${ }^{21}$ In his search, Bulosan discovered an America in his heart through Whitman:

I felt that I was at home with the young American writers and poets. Reading them drove me back to the roots of American literature-to Walt Whitman and the tumult of his time. And from him, from his passionate dream of an America of equality for all races, a tremendous idea burned my consciousness. Would it be possible for an immigrant like me to become a part of the American dream? Would I be able to make a positive contribution toward the realization of this dream? (Bulosan, 251)

The enlightened Filipino American writer now believed that America, just as Whitman advocated, should be a multi-ethnic, plural nation, a land of foreign immigrants. America was more than a geographical concept. America had to become open, free, democratic, egalitarian. As a recent immigrant, he felt justified in laying his claim to America as rightfully as the Indian and the black. When Bulosan put the following ideas into his brother Macario's mouth, he was echoing Whitman:

It is but fair to say that America is not a land of one race or one class of men. We are all Americans that have toiled and suffered and known oppression and defeat, from the first 
Indian that offered peace in Manhattan to the last Filipino pea pickers. . . All of us, from the first Adams to the last Filipino, native born or alien, educated or illiterate-We are America! (Bulosan, 189)

As Bulosan's words demonstrate, Asian Americans often have a far better grasp of Whitman's message than many white Americans. If Whitman said that he saw himself in all people, ethnic Americans rediscover in Whitman both themselves and a new America.

Garrett Kaoru Hongo is today a much acclaimed Japanese American poet. In his collection Yellow Light there is a long poem titled "Stepchild." In it Hongo recounts the historical events of various groups of Asian immigrants, reminding us of how the Chinese Americans built the railroads and laundered and were kicked out; how the Japanese Americans were forbidden by law to own land or claim citizenship, how they were sent to the relocation camps during the Pacific War; how Filipino farm workers toiled and were exploited. Yet this history written with blood and sweat has been absent in the story of American literature, as if Asian Americans were orphaned stepchildren in America. The poet asks with indignation, "Where are the histories, our tragedies, our books of fact and fiction?"22

If the history of Asian Americans was obliterated, so was Whitman's vision of the democratic, plural America buried in oblivion. In another poem, "Winnings," Hongo writes about two kinds of winnings. A poor Japanese American father won several dollars from card gambling, while his son rummaged though trash bins stuffed with used paperbacks. The son paid one dollar from Father's winnings for "four pounds" of abandoned pocket books, one of which was "a Dell that says Walt Whitman, Poet of the Open Road"' (Hongo, 20). Both the father and the son won. The son turned out to be a bigger winner because he got a good bargain on a valuable book. The reader is reminded of Louis Simpson's famous lines: "Where are you, Walt? / The Open Road goes to the used-car lot."23 Now that Japanese Americans have salvaged Whitman from the trash, maybe Whitman and his America are the real winners.

To reclaim the multi-cultural America Whitman envisioned is an endeavor shared by writers of all ethnic groups in the United States. China Men demonstrates Maxine Hong Kingston's effort to claim a Chinese America. Kingston begins her book with a story about a China man's visit to "the Land of Women" a long time ago. She seems serious: "Some scholars say that that country was discovered during the reign of Empress Wu (A.D. 694-705), and some say earlier than that, A.D. 441, and it was in North America." ${ }^{24}$ The speculation that a Chinese monk discovered "Fusang" around the fifth century was first based on an account found in an ancient Chinese chronicle. In the eighteenth century, some Western scholars and sinologists disclosed the result of their 
painstaking research and declared that Fusang was located in presentday Mexico. The debate over the Chinese discovery of the American continent is still going on.

Apparently Kingston's point in bringing up a highly controversial historical record, which is at worst a pure fantasy and at best a hypothesis, is to predate the discovery of America by one thousand years. In so doing, the whites' monopoly over America is broken and the distorted history set right. On the other hand, Kingston writes about new immigrants from China whose numbers are increasing daily. One of the chapters of her book is titled "The Making of More Americans." Her purpose is to show that the formation of American nationality is a continuous, dynamic process, far from being completed. Thus Kingston lends double legitimacy to Chinese Americans' claim to their share in both the discovery of America and the making of Americans. She might well have Whitman's endorsement for such claims. As shown in the beginning of this essay, Whitman noted that the discovery had much to do with Cathay or Asia in the first place. And he said in 1888 that the making of the American is not over: "I feel myself that the American is being made but is not made: much of him is yet in the state of dough: the loaf is not yet given shape. He will come-our American" (Traubel, $1: 201)$.

Discussing the Americanness of China Men, Kingston said in an interview, "I felt I was building, creating, myself and these people as American people, to make everyone realize that these are American people." 25 Engaged in the business of creating a new type of American, Kingston has placed herself squarely in the tradition of Whitman. She openly acknowledged that Whitman was one of her literary forefathers: "I feel that I descended from Walt Whitman." In inventing the new Chinese American Self, she was under "an empowering influence" from Whitman. ${ }^{26}$ This influence reached its peak in Kingston's novel Tripmaster Monkey. The protagonist's name is Wittman Ah Sing, a fifthgeneration Chinese American, named by his father after Whitman. Most, if not all, of the titles of the chapters of that novel are either direct borrowings from Whitman or suggestive of his imago: "Trippers and Askers" (Chapter 1); "Linguists and Contenders" (Chapter 2); "Twisters and Shouters" (Chapter 3); "Ruby Long Legs' and Zeppelin's Song of the Open Road" (Chapter 5); "A Song for Occupations" (Chapter 6); "One-Man Show" (Chapter 9). Above all, the theme of the novel is the redefining of the Chinese American identity and the enacting of a Whitmanian multicultural America.

Toward the middle of the book there is a symbolic scene: the impromptu marriage of the hero and heroine, Ah Sing and Tana. The two of them drive to San Francisco's Coit Tower. There they find a statue of Christopher Columbus "who stands with a foot on a rock and 
his nose toward the Golden Gate and the Pacific beyond."27 Visible from the tower is Angel Island where the forefathers of Chinese immigrants were once detained. Frustration, anger, and avowal of revenge are expressed in the poems carved by the detainees on the walls of the building which still stands as the silent witness of that terrible history. Then and there Wittman is reminded of his namesake and starts to recite "a mantra for this place" by the great American poet. The lines are Whitman's "Facing West From California's Shores." Ah Sing, seeking and wandering around the Bay Area, looks westward toward the other side of the Pacific, toward his land of maternity and migrations. $\mathrm{He}$ is literally retracing the steps of Whitman: "Solitary, singing in the West, I strike up for a New World" (CPCP, 176). Following his predecessor's example, Ah Sing tries to grapple with his real "Me Myself" and work out an epic play which recovers the history of Chinese Americans.

Cynical yet sincere, loafing yet tireless, Ah Sing seeks what is yet to be found, searching his Chinese American identity and a place which is called Chinese America. With the question "who am I?" constantly in mind, he becomes rebellious, just like other ethnic American writers such as Jack Kerouac, Allen Ginsberg, James Baldwin, and LeRoi Jones. He is especially bitter about the stereotyped images of Chinese Americans in literature and art. He remembers that in high school he performed with a "bearded American" mask of Whitman, with "a lot of facial hair to cover up my face and my race" (Kingston, 26). From the iconoclastic Whitman's famous exuberant beard, Ah Sing takes a hint that it is time for the Chinese American to drop the mask and keep his face/race, to reassert his real identity-no more $\mathrm{Fu}$ Man $\mathrm{Chu}$, no more Charlie Chan, no more Bret Harte's "heathen Chinese."

Kingston creates a Chinese American rebel in the figure of Wittman Ah Sing, alluding to the greatest rebel known in China and among Chinese Americans-Monkey King from The fourney to the West. The very name of the hero-witty, half-Chinese, half-American-sounds much like "Whitman I Sing."28 After learning that "a wonderful party" was being planned in heaven to which he was not invited, the Monkey, also known as Tripmaster, made havoc in heaven. Ah Sing, playing out his role as the Monkey King, is actually venting the frustration of all Chinese Americans against the discrimination they have experienced. They know only too well what it is like to be rejected in the very America that Whitman envisioned as "a race of races" (CPCP, 7). Being subjected to an exclusion law is much like being denied an invitation to a meal which Whitman "equally set" for all, with not a single person "slighted or left away" (CPCP, 205). If Ah Sing turns a rebel, doesn't he get his mandate from Whitman? 
Through her reading, Kingston arrives at her seemingly intuitive understanding of Whitman. She believes, mistakenly, that Whitman "never specifically said Chinese-ethnic Chinese also." 29 Still, she needs (to borrow Harold Bloom's term) just such a "deliberate misreading" 30 to clear imaginative space for herself. So she says, "I'd like to think he meant all kinds of people." Chinese Americans, as well as all other ethnic groups, must be included in Whitman's "vision of a new kind of human being that was going to be formed in this country." 31 Le Anne Schreiber is on target when she points out in her review of Tripmaster Monkey that Ah Sing is "American, as American as Jack Kerouac or James Baldwin or Allen Ginsberg, as American as Walt Whitman."32 Kingston brings into full play her personal and family experience, her knowledge of ethnic Chinese history, and her literary imagination in approximating what Whitman undertook to signify; she discovers in Whitman what she desires. In short, she invokes Whitman in order to espouse her own strong views on multi-culturalism.

Kingston concludes her book with Ah Sing successfully staging his grand play to which all kinds of Americans, male and female, old and young, black and white, are invited. In the midst of people embracing and kissing each other, the curtain falls with the wedding of Ah Sing and Tana, symbolic of the marriage of East and West. They have Whitman's blessing:

Europe to Asia, Africa join'd, and they to the New World, The lands, geographies, dancing before you, holding a festival garland, As brides and bridegrooms hand in hand. (CPCP, 535)

As we can see, then, the victims of the first restrictive act of Federal legislation which excluded a specific immigrant group based on race have traveled a long way. From the original sojourners to the coming of age of the fifth or sixth generation, the metamorphosis of the Asian American is a long, dynamic process that illuminates the story of American ethnogenesis. At all phases, Asian American writers have found Whitman, despite his obvious human failings, always "usual and near, removed from none" (CPCP, 316).

\section{State University of New York, Stony Brook}

\section{NOTES}

1 Walt Whitman, Notebooks and Unpublished Prose Manuscripts, ed. Edward Grier (New York: New York University Press, 1984), 1:848. Hereafter cited as NUPM.

2 Walt Whitman, Complete Poetry and Collected Prose, selected by Justin Kaplan (New York: Library of America, 1982), 533. Hereafter cited as CPCP. 
3 Thomas Brasher, Whitman as Editor of The Brooklyn Daily Eagle (Detroit: Wayne State University Press, 1970), 42-43.

4 Donald D. Kummings, ed., Walt Whitman: 1940-1975. A Reference Guide (Boston: G.K. Hall, 1982), 225.

5 James Woodress, ed., Critical Essays on Walt Whitman (Boston: G.K. Hall, 1983), 41.

6 Quoted in Zhang Longxi, The Tao and the Logos: Literary Hermeneutics, East and West (Durham: Duke University Press, 1992), 20.

7 Quoted in Mary R. Coolidge, Chinese Immigration (New York: Henry Holt, 1909; rpt. Arno Press, 1969), 96.

8 Horace L. Traubel, With Walt Whitman in Camden, Volume 1 (Boston: Small, Maynard, 1906), 113; Volume 2 (New York: Appleton, 1908); Volume 5 (Carbondale: Southern Illinois University Press, 1964); Volume 7 (Carbondale: Southern Illinois University Press, 1991).

9 Stuart C. Miller, The Unwelcome Immigrant: The American Image of the Chinese, 1752-1882 (Berkeley: University of California Press, 1969), 3.

10 Ronald Takaki, Strangers From A Different Shore: A History of Asian Americans (New York: Penguin, 1989), 16.

11 The scope of "Asian America" is still not very clearly defined. My discussion of Asian American writers, following the general practice of critics and anthologists, includes those from Chinese, Japanese, Korean, and Filipino American groups.

12 David Hsin-fu Wand, ed., Asian-American Heritage: An Anthology of Prose and Poetry (New York: Washington Square Press, 1974), 127.

13 Sadakichi Hartmann, Conversations with Walt Whitman Written in 1894 (New York: Gordon Press, 1972), 5.

14 Carlos Bulosan called Noguchi "a Japanese houseboy in the home of Joaquin Miller." See Bulosan, America Is in the Heart (New York: Harcourt, Brace, 1944), 265.

15 Yoshinobu Hakutani, "Father and Son: A Conversation with Isamu Noguchi," in fournal of Modern Literature 17 (Summer 1990), 30.

16 Lin Yutang, The Importance of Living (New York: John Day, 1937), 66.

17 Lin spent his last years in Taiwan and died there in 1976, much resented as a reactionary hack by critics on the mainland. Recently more objective studies of Lin began to appear.

18 Elaine H. Kim, Asian American Literature: An Introduction to the Writings and Their Social Context (Philadelphia: Temple University Press, 1982), 32.

19 Younghill Kang, East Goes West: The Making of An Oriental Yankee (New York: Scribner's Sons, 1937), 349.

20 Bulosan, 265.

21 Quoted in Susan Evangelista, Carlos Bulosan and His Poetry: A Biography and Anthology (Seattle: University of Washington Press, 1985), 9.

22 Garrett Kaoru Hongo, Yellow Light (Middletown: Wesleyan University Press, 1982), 58 
23 Louis Simpson, Selected Poems (New York: Paragon House, 1989), 162.

24 Maxine Hong Kingston, China Men (New York: Vintage, 1989), 5.

25 Paula Rabinowitz, "Eccentric Memories: A Conversation with Maxine Hong Kingston," Michigan Quarterly Review 116 (Winter 1987), 182.

26 Shelley Fisher Fishkin, "Interview with Maxine Hong Kingston," American Literary History 3 (Winter 1990), 790, 784.

27 Maxine Hong Kingston, Tripmaster Monkey: His Fake Book (New York: Vintage, 1989), 161.

28 John Leonard, for instance, noticed the pun on the protagonist's name. He uses it for the title of his review: "Of Thee Ah Sing." See The Nation 248 (June 5, 1989), 768.

29 Fishkin, 784.

30 Harold Bloom, The Anxiety of Influence: A Theory of Poetry (London: Oxford University Press), 5.

31 Quoted in Fishkin, 784.

32 Le Anne Schreiber, "The Big, Big Show of Wittman Ah Sing," in New York Times Book Review (April 23, 1989), 9. 